\title{
Neuregulin-1: A Potential Endogenous Protector in Perinatal Brain White Matter Damage
}

\author{
Olaf Dammann $^{\mathrm{a}-\mathrm{c}}$ Wolfgang Bueter ${ }^{\mathrm{b}}$ Alan Leviton ${ }^{c}$ Pierre Gressens ${ }^{\mathrm{d}, \mathrm{e}}$ \\ Christiane E.L. Dammann ${ }^{a, f}$ \\ aDivision of Newborn Medicine, Department of Pediatrics, Tufts-New England Medical Center, Boston, Mass., USA; \\ ${ }^{b}$ Perinatal ID Epidemiology Unit, Department of Pediatric Pulmonology and Neonatology and Department of \\ Gynecology and Obstetrics, Hannover Medical School, Hannover, Germany; ${ }^{C}$ Neuroepidemiology Unit, \\ Departments of Neurology, Children's Hospital and Harvard Medical School, Boston, Mass., USA; \\ dInserm, U676 and 'Université Paris 7, Faculté de Médecine Denis Diderot, IFR02 and IFR25, Paris, France, and \\ ${ }^{f}$ Department of Pediatric Pulmonology and Neonatology, Hannover Medical School, Hannover, Germany
}

\section{Key Words}

Infant, premature $\cdot$ Brain $\cdot$ White matter damage $\cdot$

Cerebral palsy $\cdot$ Inflammation $\cdot$ Neuregulin $\cdot$ Pathogenesis

\begin{abstract}
Brain white matter damage, an important antecedent of long-term disabilities among preterm infants, has both endogenous and exogenous components. One of the endogenous components is the paucity of developmentally regulated protectors. Here we expand on this component, discussing the potential roles of one putative protector, neuregulin (NRG)-1, in brain development and damage. We outline how NRG-1 might be involved in perinatal brain damage pathomechanisms and suggest that NRG-1 might be one target for intervention.

Copyright $\odot 2007$ S. Karger AG, Basel
\end{abstract}

\section{Introduction}

Infants born at or before 28 weeks gestation appear to be at highest risk of brain white matter damage (WMD, 18-36\%) $[1,2]$, which in turn is associated with an elevated risk of later neurologic and cognitive limitations [3]. An improved understanding of this maturityrelated risk is of major importance for those who wish to prevent it and its long-term adverse developmental consequences.

One traditional explanation is that preterm infants are (endogenously) more vulnerable to exogenous insults. Therefore, one extreme view is that improved neonatal care should lead to reduced WMD risk and improved outcome. Recent observational studies tend not to support this claim [4-7].

Another explanation is that preterm infants are more likely than their term peers to experience exogenous insults [8]. For example, intrauterine infection is both a risk factor for perinatal brain damage [9] and occurs more frequently at younger than at older gestational ages [10]. Thus, the increased WMD risk of preterm infants might reflect their higher likelihood of being exposed to adversity.

Third, low gestational age is a surrogate not only for increased vulnerability and adverse exposures, but also for many other endogenous and exogenous factors [11]. Among these are substances we have previously called 'endogenous protectors' [12]. Substances that qualify as

\section{KARGER}

() 2007 S. Karger AG, Basel

Fax +4161306 1234 E-Mail karger@karger.ch www.karger.com www.karger.com/neo
Dr. Olaf Dammann, MD, SM

Division of Newborn Medicine

Tufts-New England Medical Center and Floating Hospital for Children

750 Washington St., Boston, MA 02111 (USA)

Tel. +1 617636 0240, Fax +1 617636 8943, E-Mail odammann@tufts-nemc.org 
endogenous protectors (a) are endogenously available to the organism, (b) are protective in experimental models of disease, (c) offer biologically plausible interactions with presumed pathways of damage, and (d) are associated with a decreased risk for perinatal brain damage in humans. According to this definition, glucocorticoid and thyroid hormones [13-15] are examples for endogenous protectors.

In this article, we focus on one such potential endogenous protector, neuregulin (NRG)-1. Recent reviews of the molecular characteristics and functions of neuregulin in general [16] and in the brain $[17,18]$ are available elsewhere, as are reviews of the ErbB family of receptors necessary to signal the effects of NRG $[19,20]$. Our goal is to offer the 'big picture' that might help decide whether NRG-1 might be a candidate for perinatal neuroprotection. Our hypothesis is supported by the roles of NRG-1 in neuronal development, in potentially damaging mechanisms (hypoxia-ischemia, excitotoxicity, and inflammation), and in neuropsychiatric disorders.

\section{Neuregulin-1}

NRG-1 is the first of a family of polypeptide growth factors encoded by four distinct genes, i.e., NRG-1 [21], NRG-2 [22, 23], NRG-3 [24], and NRG-4 [25]. Our focus is on NRG-1, which has been identified in parallel by multiple groups interested in potential ligands for the ErbB2 receptor (which also goes under the names HER2 and neu), in Schwann cell development, and in a growth factor that stimulates acetylcholine receptor expression [for an overview, see 16]. Each of these groups gave the same gene a different name, i.e., heregulin [21], neu differentiation factor [26], glial growth factor [27, 28], acetylcholine receptor-inducing activity $[29,30]$, and sensory and motor neuron-derived factor [31]. In the present article, we use the name NRG-1 for all of the above, mainly for consistency.

All 16 known isoforms of NRG-1 are encoded by the same gene and result from alternative splicing and usage of different promoters [16]. A classification system (type I-III) is based on the type of epidermal growth factor (EGF)-like domain, N-terminal sequence, and initial synthesis as transmembrane or non-membrane protein [16]. Three additional types (IV-VI) are theoretically possible [32].

Neuregulin-1 and Perinatal Brain Damage

\section{ErbB Receptors}

The ErbB receptors are a family of four transmembrane receptors, that bind multiple growth factors, including EGF, transforming growth factor- $\alpha$, and NRG$1-4$, among others $[19,20]$. ErbB1, also known as the EGF receptor, does not bind NRG-1, while ErbB3 and 4 do serve as its receptors [33].

Historically, interest in ErbB receptors is rooted in their role as part of the erythroblastosis virus oncogene (v-Erb), which bears two domains in chickens, v-ErbA and v-ErbB [34]. One line of interest in NRGs and ErbB receptors is in the fields of cancer biology [35] and therapy [36]. Endogenous negative regulation of ErbB-receptor signaling might be of benefit in cancer therapy [37]. Might a 'bad' signal in tumorigenesis be 'good' in development?

\section{Neuregulins and ErbB Receptors in the Development of Myelinating Cells}

An increasing body of evidence indicates that NRG-1 and its ErbB receptors influence the growth and maturation of immature oligodendrocytes, and that maturation is disordered when a full complement of protein and receptor are not available [38-44]. Since damage to (or aberrant maturation of) developing oligodendrocytes is a likely pathogenetic factor in diffuse perinatal WMD [45], the effects of NRG-1 on developing oligodendrocytes deserve the attention of those who want to prevent WMD and its consequences.

\section{NRG in Multiple Scenarios of Perinatal Brain Damage}

Among the multiple experimental approaches to perinatal brain damage are exposure to infection/inflammation, hypoxia-ischemia, and excitotoxicity $[46,47]$. In the following sections, we briefly discuss the potential roles for NRG in these three scenarios, as well as in traumatic injury.

Perinatal brain injury, especially in the preterm newborn, is likely to have multiple causes [48]. One important possibility is that antenatal infection elicits maternal/fetal inflammatory responses $[49,50]$, which either directly damage the developing brain (e.g., via cytokine-induced damage $[12,51,52])$ and/or lead to damage by sensitizing the developing brain to subsequent hits $[47,53]$ (e.g., a

Neonatology 2008;93:182-187 
second inflammatory challenge, hypoxia-ischemia [54, 55], or free radical attack [56]). In what follows, we have listed in due brevity the potential points of intersection of NRG-1 signaling with perinatal brain damage etiology.

\section{NRG-1 and Inflammation}

An increasing body of evidence suggests that the NRGErbB-signaling system intersects with inflammatory mechanisms [57-64]. Moreover, our own unpublished observations suggest differential ErbB-heterodimerization patterns in lung type-II cells in pro- versus anti-inflammatory contexts.

In the brain, the neuroprotective effect of NRG-1 exposure prior to middle cerebral artery occlusion (v.i.) is accompanied by a prominent reduction in microglia activation and interleukin-1 mRNA expression in the penumbra, indicating a downregulation of peri-infarct inflammation by NRG-1 [65]. The hypothesis that NRG might have anti-inflammatory and anti-oxidative properties in the brain is further supported by the finding that recombinant human NRG attenuates the production of superoxide and nitrite by stimulated $\mathrm{N} 9$ microglial cells [66].

Nuclear factor $\kappa \mathrm{B}(\mathrm{NF}-\kappa \mathrm{B})$ is a nuclear component of the cell's inflammatory response [67]. NF- $\kappa B$-inducing kinase (NIK) appears to be one component of the signaling cascade initiated by proinflammatory cytokines such as tumor necrosis factor- $\alpha$, lymphotoxin- $\beta$, and interleukin-1 [68], but appears to be required only for lymphotoxin- $\beta$ signaling [69]. Within our present context, NIK appears to be recruited to all four ErbB-receptors and can activate NF- $\kappa \mathrm{B}$ in wild-type, but not in NIK-deficient cells [70]. On the other hand, recent studies find that NF$\kappa \mathrm{B}$ is not the predominant signal in white matter inflammation induced by lipopolysaccharide [71, 72].

\section{NRG-1 and Ischemic Brain Injury}

Three days after permanent middle cerebral artery occlusion (MCAO), neuregulin was prominently expressed in neurons of the penumbra [73]. In adult rat brain, ErbB4 (but not ErbB-2 and ErbB-3) protein was upregulated in neurons and macrophages/microglia in ischemic areas after MCAO [74]. From the same group comes the most interesting finding that 'a single intravascular injection of NRG-1 $\beta$ (approximately $2.5 \mathrm{ng} / \mathrm{kg}$ ) reduced cortical infarct volume by $>98 \%$ when given immediately before MCAO' [65]. Based on their observations, these authors speculate that 'the induction of ErbB receptors ... is an adaptive response ... to prevent neuronal injury' [74]. We are not aware of comparable studies in the developing brain.
$N R G$ and Excitotoxicity

Some perinatal brain damage is attributed to excitotoxicity [75]. In models of excitotoxic brain damage [76], ibotenate injection leads to neuronal loss and porencephalic cysts by acting as a glutamate analogue on the NMDA receptor $[77,78]$. In cerebellar granule cells from 9-day-old mice, NRG upregulates the expression of the NR2C-subunit of NMDA receptors [79], which appears to be associated with an increased resistance of neurons to the adverse effects of neurotoxicity [for a brief overview, see 80].

At least part of NRG's purported role in the etiology of schizophrenia [81] might be due to a link between NRG/ ErbB and glutamate/NMDA signaling [82]. In addition, NRG-1 $\beta$ appears to play a glutamate-dependent role in memory. Rats exposed to 5 weeks of learning to navigate a maze had increased brain expression of NRG-1 $\beta$, but not if they also received the glutamate blocker MK-801 [83].

\section{NRG Might Qualify as a Target for Neuroprotective Intervention}

Indirect involvement of the NRG/ErbB signaling in established protective pathways might be one avenue for the development of improved protection strategies. For example, antenatal glucocorticoid administration reduces the incidence of neonatal brain damage [84], although the long-term safety of this potentially adverse exposure has not yet been established. Might some of these effects be due to the stabilization of ErbB-receptor expression after exposure to dexamethasone and hydrocortisone $[85,86]$ ?

Direct NRG-1 administration might be feasible for animal studies designed to protect the animal's brain in the context of perinatal inflammatory, hypoxic-ischemic, and/or excitotoxic insults. The proof of principle has recently been published: NRG-1 can enter the brain after intravenous [87] and intra-arterial [65] administration. In experimental autoimmune encephalitis (one laboratory model for multiple sclerosis), systemic treatment with NRG-1 reduces demyelination and enhances remyelination [88]. This effect might not be due to NRG acting directly on oligodendroglia, but via induction of 'an environment more favorable to remyelination, possibly through modulation of the immune response' [89]. Perhaps, this is just the environment the perinatal brain needs to survive preterm birth without sustaining longterm damage. 


\section{Conclusion}

The roles discussed above for NRG-1 and its receptors in brain development and damage support our conclusion that the NRG/ErbB system might be what we have previously called an 'endogenous protector' [12]. Our own findings of enhanced late fetal lung surfactant synthesis by NRG-1 $\beta$ [90] and that all 4 ErbB receptors are present at the fetal endothelial level as early as 24 weeks gestation [91] further underscore its potential importance in the perinatal setting. Thus, NRG might be an endogenous protector in both the perinatal brain and lung. Although we are far from suggesting that NRG-1 administration might be the 'magic silver bullet' in peri- natal medicine, NRG-1 might still qualify as a potential target for exogenous indirect or even direct neuroprotective intervention.

\section{Acknowledgements}

The authors are grateful for Ron Oppenheim's comments on the manuscript.

While preparing this article, the authors were supported by grants from the Wilhelm Hirte Stiftung (Hannover), Hannover Medical School (HiLF), NIH (1 U01 NS 40069-01A2; P30-HD18655; 5K08HL004436-05), the Deutsche Forschungsgemeinschaft (Da378/3-1), Inserm, Université Paris 7, and the European Union (LSHM-CT-2006-036534).

\section{References}

1 Larroque B, Marret S, Ancel PY, Arnaud C, Marpeau L, Supernant K, Pierrat V, Roze JC, Matis J, Cambonie G, Burguet A, Andre M, Kaminski M, Breart G: White matter damage and intraventricular hemorrhage in very preterm infants: the EPIPAGE study. J Pediatr 2003; 143:477-483.

-2 Viscardi RM, Muhumuza CK, Rodriguez A, Fairchild KD, Sun CC, Gross GW, Campbell $\mathrm{AB}$, Wilson PD, Hester L, Hasday JD: Inflammatory markers in intrauterine and fetal blood and cerebrospinal fluid compartments are associated with adverse pulmonary and neurologic outcomes in preterm infants. Pediatr Res 2004;55:1009-1017.

- 3 Holling EE, Leviton A: Characteristics of cranial ultrasound white matter echolucencies that predict disability: a review. Dev Med Child Neurol 1999;41:136-139.

4 Doyle LW: Neonatal intensive care at borderline viability - is it worth it? Early Hum Dev 2004;80:103-113.

5 Hintz SR, Kendrick DE, Vohr BR, Poole WK, Higgins RD: Changes in neurodevelopmental outcomes at 18 to 22 months' corrected age among infants of less than 25 weeks' gestational age born in 1993-1999. Pediatrics 2005;115:1645-1651.

-6 Vincer MJ, Allen AC, Joseph KS, Stinson DA, Scott H, Wood E: Increasing prevalence of cerebral palsy among very preterm infants: a population-based study. Pediatrics 2006; 118:e1621-e1626.

-7 Tommiska V, Heinonen K, Lehtonen L, Renlund M, Saarela T, Tammela O, Virtanen M, Fellman V: No improvement in outcome of nationwide extremely low birth weight infant populations between 1996-1997 and 1999-2000. Pediatrics 2007;119:29-36.

-8 Leviton A, Paneth N: White matter damage in preterm newborns - an epidemiologic perspective. Early Hum Dev 1990;24:1-22.
-9 Dammann O, Kuban KC, Leviton A: Perinatal infection, fetal inflammatory response, white matter damage, and cognitive limitations in children born preterm. Ment Retard Dev Disabil Res Rev 2002;8:46-50.

$\checkmark 10$ Goldenberg RL, Hauth JC, Andrews WW: Intrauterine infection and preterm delivery. N Engl J Med 2000;342:1500-1507.

11 Leviton A, Blair E, Dammann O, Allred EN: The wealth of information conveyed by gestational age. J Pediatr 2005;146:123-127.

12 Dammann O, Leviton A: Brain damage in preterm newborns: might enhancement of developmentally-regulated endogenous protection open a door for prevention? Pediatrics 1999;104:541-550.

13 Paneth N: Does transient hypothyroxinemia cause abnormal neurodevelopment in premature infants? Clin Perinatol 1998;25:627643.

$>14$ Leviton A, Dammann O, Allred EN, Kuban KCK, Pagano M, Van Marter LJ, Paneth N, Reuss ML, Susser M, for The Developmental Epidemiology Network Investigators: Antenatal corticosteroids and cranial ultrasound abnormalities. Am J Obstet Gynecol 1999; 181:1007-1017.

15 Martin CR, Van Marter LJ, Allred EN, Leviton A: Antenatal glucocorticoids increase early total thyroxine levels in premature infants. Biol Neonate 2005;87:273-280.

16 Falls DL: Neuregulins: functions, forms, and signaling strategies. Exp Cell Res 2003;284: $14-30$.

17 Buonanno A, Fischbach GD: Neuregulin and ErbB receptor signaling pathways in the nervous system. Curr Opin Neurobiol 2001; 11:287-296.

18 Esper RM, Pankonin MS, Loeb JA: Neuregulins: versatile growth and differentiation factors in nervous system development and human disease. Brain Res Rev 2006;51:161175.
19 Yarden Y, Sliwkowski MX: Untangling the ErbB signalling network. Nat Rev Mol Cell Biol 2001;2:127-137.

20 Holbro T, Hynes NE: ErbB receptors: directing key signaling networks throughout life. Annu Rev Pharmacol Toxicol 2004;44:195217.

-21 Holmes WE, Sliwkowski MX, Akita RW, Henzel WJ, Lee J, Park JW, Yansura D, Abadi $\mathrm{N}$, Raab H, Lewis GD, et al: Identification of heregulin, a specific activator of p185erbB2. Science 1992;256:1205-1210.

22 Carraway KL 3rd, Weber JL, Unger MJ, Ledesma J, Yu N, Gassmann M, Lai C: Neuregulin-2, a new ligand of ErbB3/ErbB4-receptor tyrosine kinases. Nature 1997;387: 512-516.

23 Chang H, Riese DJ 2nd, Gilbert W, Stern DF, McMahan UJ: Ligands for ErbB-family receptors encoded by a neuregulin-like gene. Nature 1997;387:509-512.

24 Zhang D, Sliwkowski MX, Mark M, Frantz G, Akita R, Sun Y, Hillan K, Crowley C, Brush J, Godowski PJ: Neuregulin-3 (nrg3): a novel neural tissue-enriched protein that binds and activates ErbB4. Proc Natl Acad Sci USA 1997;94:9562-9567.

-25 Harari D, Tzahar E, Romano J, Shelly M, Pierce JH, Andrews GC, Yarden Y: Neuregulin-4: a novel growth factor that acts through the ErbB-4 receptor tyrosine kinase. Oncogene 1999;18:2681-2689.

-26 Peles E, Bacus SS, Koski RA, Lu HS, Wen D, Ogden SG, Levy RB, Yarden Y: Isolation of the neu/her-2 stimulatory ligand: a $44 \mathrm{kD}$ glycoprotein that induces differentiation of mammary tumor cells. Cell 1992;69:205216 .

27 Goodearl AD, Davis JB, Mistry K, Minghetti L, Otsu M, Waterfield MD, Stroobant P: Purification of multiple forms of glial growth factor. J Biol Chem 1993;268:18095-18102. 
28 Marchionni MA, Goodearl AD, Chen MS, Bermingham-McDonogh O, Kirk C, Hendricks M, Danehy F, Misumi D, Sudhalter J, Kobayashi K, et al: Glial growth factors are alternatively spliced ErbB2 ligands expressed in the nervous system. Nature 1993;362:312318.

-29 Corfas G, Falls DL, Fischbach GD: ARIA, a protein that stimulates acetylcholine receptor synthesis, also induces tyrosine phosphorylation of a $185-\mathrm{kDa}$ muscle transmembrane protein. Proc Natl Acad Sci USA 1993; 90:1624-1628.

- 30 Falls DL, Rosen KM, Corfas G, Lane WS, Fischbach GD: ARIA, a protein that stimulates acetylcholine receptor synthesis, is a member of the neu ligand family. Cell 1993; 72:801-815.

-31 Ho WH, Armanini MP, Nuijens A, Phillips HS, Osheroff PL: Sensory and motor neuron-derived factor. A novel heregulin variant highly expressed in sensory and motor neurons. J Biol Chem 1995;270:1452314532.

-32 Steinthorsdottir V, Stefansson H, Ghosh S, Birgisdottir B, Bjornsdottir S, Fasquel AC, Olafsson O, Stefansson K, Gulcher JR: Multiple novel transcription initiation sites for NRG1. Gene 2004;342:97-105.

>33 Riese DJ 2nd, Stern DF: Specificity within the EGF family/ErbB receptor family signaling network. Bioessays 1998;20:41-48.

-34 Sergeant A, Saule S, Leprince D, Begue A, Rommens C, Stehelin D: Molecular cloning and characterization of the chicken DNA locus related to the oncogene erbB of avian erythroblastosis virus. EMBO J 1982;1:237242.

-35 Roskoski R Jr: The ErbB/HER receptor protein-tyrosine kinases and cancer. Biochem Biophys Res Commun 2004;319:1-11.

36 Arteaga C: Targeting HER1/EGFR: a molecular approach to cancer therapy. Semin Oncol 2003;30(suppl 7):3-14.

>37 Sweeney C, Carraway KL 3rd: Negative regulation of ErbB family receptor tyrosine kinases. Br J Cancer 2004;90:289-293.

-38 Vartanian T, Corfas G, Li Y, Fischbach GD, Stefansson K: A role for the acetylcholine receptor-inducing protein aria in oligodendrocyte development. Proc Natl Acad Sci USA 1994;91:11626-11630.

>39 Vartanian T, Fischbach G, Miller R: Failure of spinal cord oligodendrocyte development in mice lacking neuregulin. Proc Natl Acad Sci USA 1999;96:731-735.

40 Park SK, Miller R, Krane I, Vartanian T: The ErbB2 gene is required for the development of terminally differentiated spinal cord oligodendrocytes. J Cell Biol 2001;154:12451258.

41 Calaora V, Rogister B, Bismuth K, Murray K, Brandt H, Leprince P, Marchionni M, Dubois-Dalcq $M$ : Neuregulin signaling regulates neural precursor growth and the generation of oligodendrocytes in vitro. J Neurosci 2001;21:4740-4751.
42 Kim JY, Sun Q, Oglesbee M, Yoon SO: The role of ErbB2 signaling in the onset of terminal differentiation of oligodendrocytes in vivo. J Neurosci 2003;23:5561-5571.

43 Raabe TD, Deadwyler G, Varga JW, Devries $\mathrm{GH}$ : Localization of neuregulin isoforms and erbB receptors in myelinating glial cells. Glia 2004;45:197-207.

44 Sussman CR, Vartanian T, Miller RH: The ErbB4 neuregulin receptor mediates suppression of oligodendrocyte maturation. J Neurosci 2005;25:5757-5762.

45 Leviton A, Gilles F: Ventriculomegaly, delayed myelination, white matter hypoplasia, and 'periventricular' leukomalacia: how are they related? Pediatr Neurol 1996;15:127136.

-46 Hagberg H, Peebles D, Mallard C: Models of white matter injury: comparison of infectious, hypoxic-ischemic, and excitotoxic insults. Ment Retard Dev Disabil Res Rev 2002; 8:30-38.

47 Mesples B, Plaisant F, Fontaine RH, Gressens P: Pathophysiology of neonatal brain lesions: lessons from animal models of excitotoxicity. Acta Paediatr 2005;94:185-190.

48 Dammann O, Leviton A: Inflammatory brain damage in preterm newborns - dry numbers, wet lab, and causal inference. Early Hum Dev 2004;79:1-15.

49 Leviton A, Paneth N, Reuss ML, Susser M, Allred EN, Dammann O, Kuban K, Van Marter LJ, Pagano M, Hegyi T, Hiatt M, Sanocka U, Shahrivar F, Abiri M, DiSalvo D, Doubilet P, Kairam R, Kazam E, Kirpekar M, Rosenfeld D, Schonfeld S, Share J, Collins M, Genest D, Heller D, Shen-Schwarz S: Maternal infection, fetal inflammatory response, and brain damage in very low birthweight infants. Pediatr Res 1999;46:566-575.

50 Fotopoulos S, Pavlou K, Skouteli H, Papassotiriou I, Lipsou N, Xanthou M: Early markers of brain damage in premature low-birthweight neonates who suffered from perinatal asphyxia and/or infection. Biol Neonate 2001;79:213-218.

-51 Saliba E, Henrot A: Inflammatory mediators and neonatal brain damage. Biol Neonate 2001;79:224-227.

52 Tauscher MK, Berg D, Brockmann M, Seidenspinner S, Speer CP, Groneck P: Association of histologic chorioamnionitis, increased levels of cord blood cytokines, and intracerebral hemorrhage in preterm neonates. Biol Neonate 2003;83:166-170.

53 Hagberg H, Dammann O, Mallard C, Leviton A: Preconditioning and the developing brain. Semin Perinatol 2004;28:389-395.

54 Eklind S, Mallard C, Leverin AL, Gilland E, Blomgren K, Mattsby-Baltzer I, Hagberg H: Bacterial endotoxin sensitizes the immature brain to hypoxic-ischaemic injury. Eur J Neurosci 2001;13:1101-1106.
55 Dommergues MA, Patkai J, Renauld JC, Evrard P, Gressens P: Proinflammatory cytokines and interleukin-9 exacerbate excitotoxic lesions of the newborn murine neopallium. Ann Neurol 2000;47:54-63.

56 Buonocore G, Perrone S, Bracci R: Free radicals and brain damage in the newborn. Biol Neonate 2001;79:180-186.

57 Tanaka M, Miyajima A: Oncostatin m, a multifunctional cytokine. Rev Physiol Biochem Pharmacol 2003;149:39-52.

58 Morikawa Y: Oncostatin $\mathrm{m}$ in the development of the nervous system. Anat Sci Int 2005;80:53-59.

59 Grant SL, Hammacher A, Douglas AM, Goss GA, Mansfield RK, Heath JK, Begley CG: An unexpected biochemical and functional interaction between gp130 and the EGF receptor family in breast cancer cells. Oncogene 2002;21:460-474.

60 Chen SH, Benveniste EN: Oncostatin m: a pleiotropic cytokine in the central nervous system. Cytokine Growth Factor Rev 2004; 15:379-391.

61 Qiu Y, Ravi L, Kung HJ: Requirement of ErbB2 for signalling by interleukin-6 in prostate carcinoma cells. Nature 1998;393: 83-85.

62 Hemi R, Paz K, Wertheim N, Karasik A, Zick Y, Kanety H: Transactivation of ErbB2 and ErbB3 by tumor necrosis factor-alpha and anisomycin leads to impaired insulin signaling through serine/threonine phosphorylation of IRS proteins. J Biol Chem 2002;277: 8961-8969.

63 Greene LA, Tischler AS: Establishment of a noradrenergic clonal line of rat adrenal pheochromocytoma cells which respond to nerve growth factor. Proc Natl Acad Sci USA 1976;73:2424-2428.

64 Erlich S, Goldshmit Y, Lupowitz Z, PinkasKramarski R: ErbB-4 activation inhibits apoptosis in PC12 cells. Neuroscience 2001; 107:353-362.

-65 Xu Z, Jiang J, Ford G, Ford BD: Neuregulin-1 is neuroprotective and attenuates inflammatory responses induced by ischemic stroke. Biochem Biophys Res Commun 2004;322: 440-446.

66 Dimayuga FO, Ding Q, Keller JN, Marchionni MA, Seroogy KB, Bruce-Keller AJ: The neuregulin GGF2 attenuates free radical release from activated microglial cells. J Neuroimmunol 2003;136:67-74.

67 Barnes PJ, Karin M: Nuclear factor-kappaB: a pivotal transcription factor in chronic inflammatory disease. N Engl J Med 1997;336: 1066-1071.

68 Malinin NL, Boldin MP, Kovalenko AV, Wallach D: MAP3K-related kinase involved in NF-kappaB induction by TNF, CD95 and IL-1. Nature 1997;385:540-544.

-69 Yin L, Wu L, Wesche H, Arthur CD, White JM, Goeddel DV, Schreiber RD: Defective lymphotoxin-beta receptor-induced NFkappaB transcriptional activity in NIK-deficient mice. Science 2001;291:2162-2165. 
70 Chen D, Xu LG, Chen L, Li L, Zhai Z, Shu HB: NIK is a component of the EGF/heregulin receptor signaling complexes. Oncogene 2003;22:4348-4355.

-71 Briscoe T, Duncan J, Cock M, Choo J, Rice G, Harding R, Scheerlinck JP, Rees S: Activation of NF-kappaB transcription factor in the preterm ovine brain and placenta after acute LPS exposure. J Neurosci Res 2006;83: 567-574.

72 Uesugi M, Nakajima K, Tohyama Y, Kohsaka S, Kurihara T: Nonparticipation of nuclear factor kappa B (NFkappaB) in the signaling cascade of c-Jun N-terminal kinase (JNK)and p38 mitogen-activated protein kinase (p38MAPK)-dependent tumor necrosis factor alpha (TNFalpha) induction in lipopolysaccharide (LPS)-stimulated microglia. Brain Res 2006;1073-1074:48-59.

-73 Parker MW, Chen Y, Hallenbeck JM, Ford BD: Neuregulin expression after focal stroke in the rat. Neurosci Lett 2002;334:169-172.

74 Xu Z, Ford BD: Upregulation of erbB receptors in rat brain after middle cerebral arterial occlusion. Neurosci Lett 2005;375:181186.

75 Spedding M, Evrard P, Gressens P: Neuroprotection in the newborn infant: interactions between stress, glutamate, glucocorticoids and development. Dev Med Child Neurol Suppl 2001;86:10-12.

-76 Marret S, Mukendi R, Gadisseux JF, Gressens P, Evrard P: Effect of ibotenate on brain development: an excitotoxic mouse model of microgyria and posthypoxic-like lesions. J Neuropathol Exp Neurol 1995;54:358-370.
77 Gressens P, Marret S, Evrard P: Developmental spectrum of the excitotoxic cascade induced by ibotenate: a model of hypoxic insults in fetuses and neonates. Neuropathol Appl Neurobiol 1996;22:498-502.

78 Tahraoui SL, Marret S, Bodenant C, Leroux P, Dommergues MA, Evrard P, Gressens P: Central role of microglia in neonatal excitotoxic lesions of the murine periventricular white matter. Brain Pathol 2001;11:56-71.

79 Ozaki M, Sasner M, Yano R, Lu HS, Buonanno A: Neuregulin-beta induces expression of an NMDA-receptor subunit. Nature 1997; 390:691-694.

80 Nicoletti F, Bruno V, Catania MV, Battaglia G, Copani A, Barbagallo G, Cena V, Sanchez-Prieto J, Spano PF, Pizzi M: Group-I metabotropic glutamate receptors: hypotheses to explain their dual role in neurotoxicity and neuroprotection. Neuropharmacology 1999;38:1477-1484.

81 Corfas G, Roy K, Buxbaum JD: Neuregulin 1-erbB signaling and the molecular/cellular basis of schizophrenia. Nat Neurosci 2004;7: 575-580.

82 Hahn CG, Wang HY, Cho DS, Talbot K, Gur RE, Berrettini WH, Bakshi K, Kamins J, Borgmann-Winter KE, Siegel SJ, Gallop RJ, Arnold SE: Altered neuregulin 1-erbB4 signaling contributes to NMDA receptor hypofunction in schizophrenia. Nat Med 2006; 12:824-828

83 Schillo S, Pejovic V, Hunzinger C, Hansen T, Poznanovic S, Kriegsmann J, Schmidt WJ, Schrattenholz A: Integrative proteomics: functional and molecular characterization of a particular glutamate-related neuregulin isoform. J Proteome Res 2005;4:900-908.

-84 O'Shea TM, Doyle LW: Perinatal glucocorticoid therapy and neurodevelopmental outcome: an epidemiologic perspective. Semin Neonatol 2001;6:291-307.
85 Karlan BY, Jones J, Slamon DJ, Lagasse LD: Glucocorticoids stabilize HER-2/neu messenger RNA in human epithelial ovarian carcinoma cells. Gynecol Oncol 1994;53:7077.

86 Dammann CE, Nassimi N, Liu W, Nielsen $\mathrm{HC}$ : ErbB receptor regulation by dexamethasone in mouse type ii epithelial cells. Eur Respir J 2006;28:1117-1123.

-87 Kastin AJ, Akerstrom V, Pan W: Neuregulin1-beta1 enters brain and spinal cord by receptor-mediated transport. J Neurochem 2004;88:965-970.

88 Cannella B, Hoban CJ, Gao YL, Garcia-Arenas R, Lawson D, Marchionni M, Gwynne D, Raine CS: The neuregulin, glial growth factor 2, diminishes autoimmune demyelination and enhances remyelination in a chronic relapsing model for multiple sclerosis. Proc Natl Acad Sci USA 1998;95:1010010105

89 Penderis J, Woodruff RH, Lakatos A, Li WW, Dunning MD, Zhao C, Marchionni M, Franklin RJ: Increasing local levels of neuregulin (glial growth factor-2) by direct infusion into areas of demyelination does not alter remyelination in the rat CNS. Eur J Neurosci 2003;18:2253-2264.

$\checkmark 0$ Dammann CE, Nielsen HC, Carraway KL 3rd: Role of neuregulin-1 beta in the developing lung. Am J Respir Crit Care Med 2003; 167:1711-1716.

91 Bueter W, Dammann O, Zscheppang K, Korenbaum E, Dammann CE: ErbB receptors in fetal endothelium - a potential linkage point for inflammation-associated neonatal disorders. Cytokine 2006;36:267-275. 